\title{
MARITAL BREAKUP IN LATER ADULTHOOD AND SELF-RATED HEALTH: A CROSS-SECTIONAL SURVEY IN SWITZERLAND
}

Bina Knöpfli ${ }^{1}$, Stéphane Cullati ${ }^{2}$, Delphine S. Courvoisier ${ }^{2}$, Claudine Burton-Jeangros ${ }^{2} \&$ Pasqualina Perrig-Chiello $^{1}$ 1 University of Bern, Switzerland

THEORETICAL BACKGROUND AND RESEARCH AIMS

Empirical research has emphasised the strong link between marital status and health. In general, separated, divorced or widowed persons have poorer physical functioning, lower self-rated health (SRH) and a higher mortality risk than their married counterparts. More recent studies however suggest that relationship status (i.e. having a partner or not), and not marital status per se, has an impact on health outcomes.

A limitation in research to date is that most empirical studies have focused on the impact of marital disruption on health outcomes in younge adults. Considering the significant increase of divorce rates among adults aged 50 and older, this represents a major research gap.

Aims and Hypotheses:

The aims of this study are:

To explore the differences between three groups of individuals with different relationship statuses: marital breakup and repartnered, marital breakup and single and continuously married with regard to SRH as well as intrapersonal and social resources.

To examine the predictive power of relationship status with regard to SRH when controlling for age and other potentially confounding variables such as gender, age, duration and satisfaction with ex-relationship, national origin, education and financial resources.

To explore the moderating role of intrapersonal resources (i.e. personality traits and resilience) and social resources (i.e. reported social and emotional loneliness) in the relationship status and SRH association.

Based on theoretical insights (Amato's Model, 2000) and the status quo of research, we hypothesize among other that:

We expect that individuals living in a relationship - independent of their marital status - will show better SRH than their single counterparts.

We expect that relationship status remains significantly related to SRH even after controlling for these variables.

We hypothesize that the better the intrapersonal and social resources, the better the SRH among individuals with a marital breakup.

${ }^{2}$ University of Geneva, Switzerland

contact: bina.knoepfli@psy.unibe.ch

\begin{tabular}{|c|c|c|c|c|}
\hline \multicolumn{5}{|c|}{ METHODS } \\
\hline \multirow{5}{*}{$\begin{array}{l}\text { - Data presented were gathered in a first wave of the } \\
\text { prospective questionnaire study 'Vulnerability and } \\
\text { growth: Developmental dynamics and differential } \\
\text { effects of the loss of an intimate partner in the 2nd life } \\
\text { half', which is part of the Swiss National Centre of } \\
\text { Competence in Research 'LIVES - Overcoming } \\
\text { vulnerability: life course perspectives' (funded by the } \\
\text { Swiss National Science Foundation). } \\
\text { - A random sample was supplied by the Swiss Federal } \\
\text { Office of Statistics, furthermore participants were } \\
\text { recruited by advertisements. }\end{array}$} & \multicolumn{4}{|l|}{ Table 1. Sample Description } \\
\hline & & $\begin{array}{c}\text { Continuously } \\
\text { married } \\
(n=399)\end{array}$ & $\begin{array}{c}\text { Repartnered } \\
\text { divorcees }\end{array}$ & $\begin{array}{l}\text { Single divorcees } \\
\qquad(n=532)\end{array}$ \\
\hline & $\begin{array}{l}n \text { (women/men) } \\
\text { Age in years (SD) (Range: 40-65) }\end{array}$ & $\begin{array}{c}399(226 / 173) \\
52.3(7.9)\end{array}$ & $\begin{array}{l}424(205 / 219) \\
51.1(7.2)\end{array}$ & $\begin{array}{c}532(385 / 147) \\
52.3(6.8)\end{array}$ \\
\hline & $\begin{array}{l}\text { Duration of (ex-) relationship, in } \\
\text { years (SD) }\end{array}$ & $27.89 .7)$ & $17.4(9.2)$ & $21.1(8.9)$ \\
\hline & & & & \\
\hline
\end{tabular}

RESULTS

Table 2. Self-rated health by relationship status

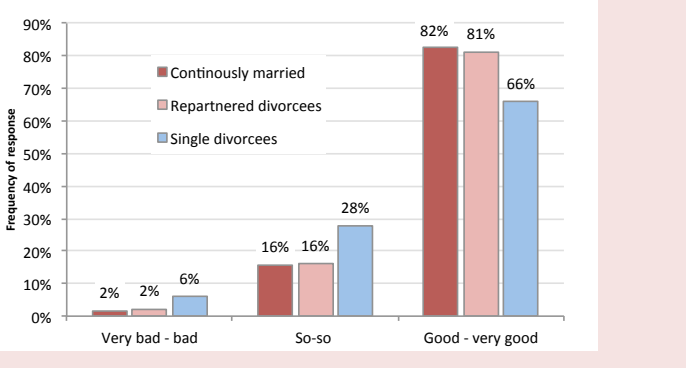

Table 3. Linear regression analyses predicting $\mathrm{SRH}^{\mathrm{a}}$, unadjusted and adjusted

\begin{tabular}{|c|c|c|c|c|c|c|c|c|c|}
\hline & \multicolumn{3}{|c|}{ Unadjusted } & \multicolumn{3}{|c|}{$\begin{array}{l}\text { Adjusted } \\
(N=1302)\end{array}$} & \multicolumn{3}{|c|}{$\begin{array}{l}\text { Adjusted, in the subgroup of } \\
\text { respondent with marital breakup } \\
(N=911)\end{array}$} \\
\hline & $B$ & $95 \% \mathrm{Cl}$ & $p$ & $B$ & $95 \% \mathrm{Cl}$ & $p$ & $B$ & $95 \% \mathrm{Cl}$ & $p$ \\
\hline \multicolumn{10}{|l|}{ Marital breakup (ref.: No) } \\
\hline & $\begin{array}{r}0.008 \\
-0.231\end{array}$ & $\begin{array}{l}-0.084,0.100 \\
-0.31,-0.144\end{array}$ & $\begin{array}{l}0.870 \\
<0.001\end{array}$ & $\begin{array}{l}-0.028 \\
-0.214\end{array}$ & $\begin{array}{l}-0.179,0.123 \\
-0.402-0.026\end{array}$ & $\begin{array}{l}0.712 \\
0.026\end{array}$ & -0.193 & $-0.309-0.077$ & 0.001 \\
\hline Number of years in couple & 0.004 & $0.002,0.007$ & 0.001 & -0.001 & $-0.007,0.005$ & 0.700 & $\begin{array}{r}-0.003 \\
-0.003\end{array}$ & $-0.013,0.007$ & 0.515 \\
\hline & -0.003 & $-0.008,0.002$ & 0.181 & -0.004 & $-0.009,0.002$ & 0.179 & 0.000 & $-0.008,0.008$ & 0.979 \\
\hline \multirow{2}{*}{\multicolumn{9}{|c|}{ 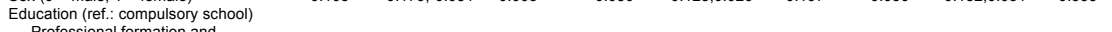 }} & 0.333 \\
\hline Professional formation and & & $-0.060,0.230$ & 0.251 & & & & & & \\
\hline $\begin{array}{l}\text { secondary } \\
\text { Technical college }\end{array}$ & 0.219 & $0.068,0.370$ & 0.004 & 0.069 & $\begin{array}{l}-0.0047,0.234 \\
-0.0460 .254\end{array}$ & $\begin{array}{l}0.415 \\
0.175\end{array}$ & $\begin{array}{l}0.101 \\
0.200\end{array}$ & 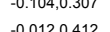 & 0.064 \\
\hline $\begin{array}{l}\text { lectnincal college } \\
\text { University }\end{array}$ & 0.198 & $0.034,0.363$ & 0.018 & 0.026 & $-0.116,0.169$ & 0.718 & 0.162 & $\begin{array}{l}-0.012,0.412 \\
-0.065,0.389\end{array}$ & 0.162 \\
\hline \multicolumn{10}{|l|}{$\begin{array}{l}\text { Satisfaction with financial situation } \\
\text { (ref: more than enough money) }\end{array}$} \\
\hline Enough money & -0.231 & $-0.333,-0.129$ & $<0.001$ & -0.184 & $-0.292,-0.077$ & 0.001 & -0.127 & $-0.275,0.021$ & 0.093 \\
\hline \multirow{3}{*}{$\begin{array}{l}\text { Not enough money } \\
\text { Origin (not Swiss) } \\
\text { Duration (years) of ex-relationship } \\
\text { Reported possibilities of development } \\
\text { and support in ex-relationship }\end{array}$} & -0.677 & $-0.813,-0.540$ & $<0.001$ & -0.583 & $-0.729,-0.437$ & $<0.001$ & -0.567 & $-0.757,-0.377$ & $<0.001$ \\
\hline & $\begin{array}{l}-0.055 \\
-0.004\end{array}$ & $\begin{array}{l}-0.154,0.044 \\
-0.009,0.002\end{array}$ & $\begin{array}{l}0.278 \\
0.168\end{array}$ & -0.054 & $-0.153,0.045$ & 0.285 & $\begin{array}{l}-0.049 \\
-0.004\end{array}$ & $\begin{array}{l}-0.176,0.078 \\
-0.010,0.002\end{array}$ & $\begin{array}{l}0.448 \\
0.217\end{array}$ \\
\hline & 0.042 & $0.002,0.081$ & 0.038 & - & . & . & 0.026 & $-0.014,0.065$ & 0.201 \\
\hline & & & & & & & & & \\
\hline
\end{tabular}

DISCUSSION

- Our findings confirm that marital breakup is associated with lower self-rated health, but only when relationship status is considered. Single divorcees had the lowest self-rated health scores, whereas their repartnered counterparts reported comparable scores with the continuously married.

- In contrast to their single counterparts, repartnered divorcees reported significantly higher scores in openness, agreeableness and extraversion and lower scores in neuroticism. These results substantiate other findings showing that specific personality traits can facilitate the process of adaptation to divorce. The same holds for resilience, a personality trait that is known to facilitate coping with critical life events.

- The only significant predictor for SRH along with relationship-status was satisfaction with the financial situation. This result is supported by existing literature which suggests that single divorcees complain more frequently about financial difficulties than their repartnered counterparts.

- Our results suggest that independent of the life stage and its specific stressors (e.g. being responsible for underage children in younger midlife or being confronted with familial expectations of help and care for elderly parents in older midlife), relationship status has an impact on SRH.

Results will be validated with longitudinal data gathered in the second wave in spring 2014

\section{FNSTF}

SWiss National SCIEnCE Foundation
2015 International Health Conference, St Hugh's College, Oxford June 25th -27th, 2015

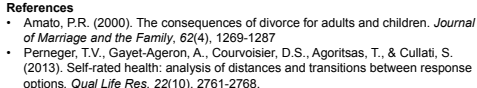

